\title{
From Weberian Bureaucracy to Networking Bureaucracy
}

\author{
Vadim Kvachev \\ Candidate of Sociological Sciences, Senior Lecturer, Plekhanov Russian University of Economics \\ Address: Stremyanny lane, 36, Moscow, Russian Federation 117997 \\ E-mail: kvachevvg@mail.ru
}

\begin{abstract}
Max Weber viewed organizational bureaucracy as one of the inevitable premises for genesis of capitalism, and his concept of bureaucracy has been the authoritative instrument in the analysis of organizations for many years. The Fordist Modern social organization cannot be imagined without bureaucratic organization. Up to recent times, bureaucratic organization, existing as a general pattern of organizing social life, seemed to prove to be the ultimate efficiency as a means of organizing governmental bodies as well as big corporations. Today, Weberian bureaucracy as theory and practice come under criticism as rigid, obsolete, and ineffective. Under the conditions of late capitalism, modern organization is claimed to be more flexible and more adaptive to changes. It is my belief that the phenomenon of bureaucracy cannot be analyzed in isolation from other theories of social order. With its strict rules and regulations, Weberian bureaucracy is the embodiment of Foucauldian disciplinary power at the organizational level. Foucault's diagrams expressing power through systematic relations between humans, objects, and spaces could be the perfect study of bureaucracy. Bureaucracy changes with the transition from disciplinary power relations to postmodern power relations. The traditional disciplinary instruments (rules, codes, and regulations) give space for more flexible and even (at first sight) democratic inter-organizational relations. However, this supposed freed without freedom has its priceк. Deregulation paradoxically leads to even more regulation, which now appears as self-control and self-surveillance. Being microscopic (mostly due to novel technological opportunities) and de-regulative at the same time, this new networking bureaucracy restructures power relations in organizations in a way that produces behavior leading to atomization and individualization without a freedom.
\end{abstract}

Keywords: Max Weber, Michel Foucault, bureaucracy, networks, neoliberalism

Social sciences owe Max Weber so much that we could truly consider him as one of the founding fathers of sociology. The notions of Modernity, rationality, social action, and social stratification were first introduced or at least significantly developed by Weber.

Max Weber's concept of bureaucracy has been the authoritative instrument in the analysis of organizations for many years. Organizational bureaucracy was viewed by Max Weber as one of the inevitable premises for the genesis of capitalism. For Weber, the transition from the traditional to the Modern capitalist modes of governing is connected with a set of specific rules providing for the rationalization and systematization of institutions and social activities. The origins of these rules lay in Protestant ethics, and resulted in the disenchantment of the social space.

(c) Vadim Kvachev, 2019

(c) Centre for Fundamental Sociology, 2019

DOI: $10.17323 / 1728-192 \mathrm{X}-2019-2-28-40$ 
Due to rationalization, society is no longer imagined as being established as the domain of eternal laws. Individuals who imagined themselves as being rational restructured the social space once driven by tradition hierarchies to intentionally-ordered structures known as bureaucracies.

Weberian bureaucratic organization (Weber 1978: 956-958) implies strict jurisdictional areas attached to the worker's position, identifying their functions and ability to act. It is constructed as a hierarchy of organizational positions from top to bottom levels, and it requires special training and focused specialization from the members of the organization. It consists of professionals whose lifelong vocation is bureaucratic work and thus, their working full-time. It is based on written documents, and it is regulated by general, objectified rules which do not depend on personal will.

The Fordist Modern social organization cannot be imagined without bureaucratic organization. The word "bureaucracy" obtained a negative connotation, although in fact the above-mentioned mode of organizational governing is rather typical than abnormal in the modern world. Up to recent times, the bureaucratic organization seemed to prove its ultimate efficiency as a means of organizing governmental bodies as well as big corporations; it existed as a general pattern of organizing social life.

Today, the Weberian bureaucracy as theory and practice come under criticism as rigid, obsolete, and ineffective. Modern organization under the conditions of late capitalism is claimed to be more flexible and adaptive to changes. The question is could the Weberian bureaucracy still be the key pillar in structuring organizations in the fast-changing, highly-competitive global world?

To see how Weberian bureaucracy has changed in the modern world, we should consider the evolution of its elements. It is very important to look at how Post-modernity has influenced classic organizational structures.

It is my belief that the phenomenon of bureaucracy cannot be analyzed in isolation from other theories of social order. Weberian bureaucracy with its strict rules and regulations is the embodiment of Foucauldian disciplinary power at the organizational level. Foucault's diagrams (Deleuze, 2006), expressing power through systematic relations between humans, objects, and spaces, could be an example of the perfect study of organizational systems. Is there a more colorful representation of classic Weberian bureaucracy than the diagram of the office space with strict rules, a dress-code, and a chain of command incarnating certain power relations aimed to discipline and organize obedient workers in an "objective" structured hierarchy? Moreover, there is also interesting parallel between Foucault's theory of power/knowledge and Weber's recognition of the role of information in the bureaucratic administration (Swedeberg, Agevall, 2005). I want to use the lenses of Foucauldian analysis to demonstrate the relevance of the Weberian bureaucratic concept in a Modern organizational structure analysis and its modification in the Post-modern era.

While defining bureaucracy, Weber writes that the idea of jurisdictional areas is essential for this notion. The bureaucracy is based on the rules, laws, or administrative regulations defining particular activities: "The regular activities required for the purpose of 
the bureaucratically governed structure are assigned as official duties" (Weber, 1978: 956). In other words, the regular work done by the organization is recognized, systematized, and legalized. The jurisdictional area is exactly the legal provision of the actual work to be done by the organization. This requires the task of creating a system of knowledge that connects a particular set of work with its legal recognitions. We can assume powerknowledge relations where knowledge produces power, and power constitutes knowledge (Foucault, 1975: 27-28). According to Foucault, this process of the creation of power and knowledge structures is parallel, that is, the object becomes a subject of a power relation at the same time as systematic knowledge is collected. The system of knowledge becomes the discursive provision for the system of action intended by power. Weber himself spots this correlation between power and knowledge in establishing a bureaucratic structure: "Bureaucratic administration means fundamentally domination through knowledge. This is the feature of it that makes it specifically rational. This consists on the one hand in technical knowledge which, by itself is sufficient to ensure it a position of extraordinary power. But, in addition to this, bureaucratic organizations, or the holders of power who make use of them, have the tendency to increase their power still further by the knowledge growing out of experience in the service" (Weber, 1925). Thus, Weber's concept of bureaucratic knowledge obtained through rational thinking and experience is very similar to the Foucauldian idea of power-knowledge. Knowledge constitutes rules, and rules determine authority, becoming its source and sine qua non at the same time.

The system of rules and regulation provides a system of the distribution of authority from top-level management to every element of the organization; integer authority is granulated into small pieces, each of which is attributed to every official. The jurisdictional areas delimitate these pieces of authority delegated from the entire authority of the organization as a whole: "The authority to give the commands required for the discharge of these duties is distributed in a stable way and is strictly delimited by rules concerning the coercive means, physical, sacerdonal or otherwise, which may be displaced at the disposal of officials. Methodical provision is made for the regular and continuous fulfilment of these duties and for the exercise of the corresponding rights, only persons who qualify under general rules are employed" (Weber, 1978: 956). The position of the official in the bureaucracy is defined through rules and rational knowledge. Rational knowledge gained by professionals determines rules, rules determine duties, and duties determine activities and the work of the official. The system of empowerment in the bureaucracy exists through obtaining and imposing certain rational knowledge about what to do and how to do it. This is exactly what Weber called the "iron cage."

The Weberian bureaucratic organization is a representation of rational Modern industrial production in non-material sectors such as management, service, and information production. In this context, we should bear in mind that Weber conducted a detailed analysis of the genesis of capitalism. His analysis of bureaucracy is the extension of his research agenda devoted to exploring rationality in Modern society.

The triumph of rationality in industrial production was embodied in the Fordist factory with its detailed division of labor, task-specific workplaces, and the explicit system 
of worker-efficiency regulation. Weberian bureaucracy was an incarnation of the same principles long before the exquisite Fordist factory saw the light of day. The principles of the constant rationalization of activities tested in the laboratory conditions of 19th century European continental bureaucracy were later implemented in highly-competitive American business.

However, it is exactly the rationalized knowledge that was the grounding for both. In this case, Foucault uses the term of "analytical space" (1975: 143), the space of systematized knowledge distributed among individuals in the organization according to their place, status, functions, and other categories. The analytical space overlaps the systematized knowledge of individuals and objects in the organizational space, thus determining their status. It may be no accident that the typical representation of the repository of this type of knowledge is the file-cabinet (French bureau), as the bureaucracy starts with this systematized information. Furthermore, Weber put it this way: "The management of modern office is based upon written documents (the 'files') . . . and upon a staff and subaltern officials and scribes of all sorts. The body of officials working in an agency along with respective apparatus of material implements and the files makes up a bureau" (Weber, 1978: 957)

The bureaucratic analytical space is organized through the codification and description of knowledge in certain forms. This produces a huge amount of instructions, written orders, and other types of documents which are systematized in this bureau. Weber also outlines the need to create a specific class of officials providing the work of organization with the sustaining of this analytical space in order. In Foucauldian terms, they keep the analytical space, and are authorized to verify its reality with the knowledge from the analytical space (truth) producing knowledge/power. A bureaucracy divides its supreme authority into particles and uses the written documents verified according to analytical space by the authorized class of workers to redistribute it among its officials, attributing predefined jurisdictional areas to each of them. This distribution is settled as a system of general rules that is obligatory for every member of the bureaucratic organization: "The management of the office follows general rules, which are more or less stable, more or less exhaustive, and which can be learned. Knowledge of these rules represents a special technical expertise which the officials possess" (Weber, 1978: 958).

A bureaucracy is constituted from the analytical space provided by power/knowledge, resulting in general rules and jurisdictional areas of each individual in the organization, and manifests itself in creating a social superstructure called a hierarchy, that is, the systematization of these officials in a certain order: "The principles of office hierarchy and of channels of appeal stipulate a clearly established system of super- and sub-ordination in which there is a supervision of the lower offices by the higher ones. Such a system offers the governed the possibility of appealing in a precisely regulated manner, the decision of a lower office to the corresponding superior authority" (Weber, 1978: 957).

A hierarchy is an embodied analytical space that distributes individuals in social and organizational spaces. A hierarchy is important because it identifies who can wield influence on the analytical space in order to change it, and thus change regulations and 
the authority distribution. The highest levels of bureaucratic officials exercise power on the basis of objectified rules, and could change these rules changing the analytical space (for example, by issuing orders or regulations). Officials at the middle and lower levels of hierarchy have to obey these rules, although they can resolve uncertain situations or situations beyond their jurisdictional area using "channels of appeal" to the highest levels.

At the level of the individual official, this results in the creation of detailed professional specializations and specified working positions: "When the office is fully developed, official activity demands the full working capacity of the official, irrespective of the fact that length of this obligatory working hours in the bureau may be limited" (Weber, 1978: 958). In other words, the specific workplace created in the organizational hierarchy of the bureaucracy requires training and specialization, and full-time work as a lifelong (or at least long-term) vocation.

As part of a bureaucracy, the specially trained and fully-employed individual alienates part of his life (the working hours) to the organization in which they work; in the same way, they alienate part of their personality in the form of their skills and abilities. The bureaucrat becomes a werewolf: an official worker of a bureaucracy in daylight and a private individual at night. This transformation take place in the arena of constantly changing purposes, focuses, and aims of personal activity. While being an official, the individual pursues the purposes of the organization in which they are employed; as a private person, they seek a salary for their work and to pursue their own needs and desires.

Inside the bureaucratic organization, the behavior of an individual falls under the controls of the analytical space. Foucault describes disciplinary control in terms of imposing time-tables (establishing rhythms, imposing particular occupations, or regulating the cycles of repetition), the measuring and elaborating of the working activity, and the correlation of body and gestures resulting in body-object articulation, relations that the body must have with the object that it manipulates (1975: 149). While the third instrument was actively used mostly in Fordist factories with its manual labor, the first two are the good examples of correlating the analytical space with the practical activity of bureaucratic workers.

The working life of the official is measured and evaluated according to the bureaucratic norms of working time, while the activities performed during this time are scrupulously described in special documents referred to their jurisdictional area. In other words, during any particular day, almost each work-step of a bureaucrat is classified and described in a set of special documents usually known as job instructions or duty regulations.

This is also relevant to job content, because bureaucratic work requires specific skills obtained through education: "Office management . . . usually presupposes thorough training in a field of specialization. This, too, holds increasingly for the modern executive and employee of a private enterprise, just as it does for the state of officials" (Weber, 1978: 958). In terms of training, the skills of a bureaucrat are also controlled and measured by means of the analytical space. To implement their duties, the official should prove to have certain qualities and skills themselves. The system of the evaluation of an official is also 
established as part of the analytical space attaching certain qualifications characteristic to each job position, as well as the instruments to measure them.

Thus, the life of the bureaucratic worker is split in two parts, separating their social and professional life as an official subject, and their private life as a natural person. A bureaucracy pretends to rule the first one to be delimitated by working hours and working duties, while the second is a matter of self-management or household activities aimed at the reproduction of the individual's labor potential through the satisfaction of needs.

Let me put this in a way similar to the argument of Giorgio Agamben (1998) about the constituting of the state apparatus from the rejection of part of human life; the Weberian bureaucracy separates the individual from its naked life (biological needs and demands) and rejects the former. In the Weberian bureaucracy, the individual is official and nothing more since that is how this objectified inhumane structure works. To be a bureaucrat, one should do their best to isolate personality to become a part of what Foucault called a machine, meaning inexorable, rationalized systems of operating reality (1975: 163). To be an element of the machine, individuals should become an element that may be placed, moved, or articulated by others; to follow the various chronological series that discipline must combine to form a composite time of his work; and to be a subject of the precise system of command (Ibid.: 162-169). All of these qualities described are essential characteristics of the Weberian bureaucracy, which is a concrete representation of a social organizational machine.

In the tradition of the Foucauldian method, I should elaborate this theoretical model by conducting a diagrammatic analysis of bureaucracy. In other words, I should accomplish the analysis with diagrams, that is, technical and spatial conditions of the functioning of bureaucracy. The following description will be as general as possible because it should cover a general definition of the diagram in private corporations, as well as in public-sector bodies.

The typical diagram of Weberian bureaucracy is of course the office, a space in which the workplaces of bureaucratic workers are organized with a specific logic, and divided according to the principle of hierarchy by organizational departments. In the old-fashioned bureaucracy, each department has its own separate room while more modern organizations tend to have open spaces. In both cases, the highest levels of the administration usually have their own offices. The workplace of the bureaucratic worker usually consists of a table, a chair and a computer, but sometimes with office appliances. The daily responsibilities of a bureaucratic worker consist of working with files on the computer and communicating with colleagues, customers, or suppliers in person and through means of the telephone and the Internet. For the modern bureaucracy, it is typical to have its workers be present at the workplace for the entire day, except for officially-restricted work-breaks. Working duties are planned and described, and work-schedules and tasks are defined by the line managers. All violations of task deadlines and work routines are treated as inconsistent with the job.

The skills and abilities of bureaucratic workers are evaluated according to a predefined system of the human-resources management. This special evaluation is imposed to mea- 
sure the efficiency and productivity of an office worker, and of required results for rewards or punishment.

What is it that makes a bureaucracy a perfect social machine? Based on the arguments listed above, I could outline two essential premises; the separation of the individual into two parts, professional and personal, with the rejection of the latter from the workspace, and the rationalization and structuring of social chaos into a solid organizational order subjugated to the aim of attaining efficiency and productivity. In the first case, bureaucracy generates a specific individual subject, a wholesome professional who has no room for private affection and thoughts in their mind; in the second case, it develops a wholesome organization which creates rules and borders to differentiate itself from the external chaos of the free market unifying professionals in pursuing collective goals. The bureaucracy thus is rather a specific mode of relation between the organization and the individual in this context than just a social institution (Maravelias, 2003: 551-552).

The theory of bureaucracy has influenced the social and economic theory of organization, and researchers have conducted many studies on the topic: R. K. Merton (1952), P. M. Blau (1956), E. Jacques (1986), W. A. Niskanen (2007), J. Q. Wilson (1991), P. Evans and J. E. Rauch (1999), and others. The concept of bureaucracy was found to be relevant in describing the social structure and consistent pattern of functioning of the organization. In 1937, in The Nature of the Firm, the famous economist Ronald Coase tried to formulate an economic explanation to the question of why firms are organized according to structural hierarchical principles which are different from free market patterns.

Nearly a century after Max Weber's death, the word "bureaucracy" has, at the same time, become a synonym for inefficiency, rigidity, the inability to adapt, and even for inhumanity. Several theoretical and practical attempts have been made to uncrown bureaucracy and promote different forms of organization. In the public sector, one of the most notable attempts resulted in the book called Reinventing Government (Osborne, Gaebler, 1992). The authors, D. Osborne and T. Gaebler, propose to deconstruct the bureaucracy in the public sector, and reorganizing it according to the principles of the private sector. According to D. Argyriades (2010), the Osbourne-Gaebler model of decentralization, deregulation, and the downsizing and outsourcing of the public bureaucracy has strongly influenced the patterns of managing structural changes in governmental organizations.

Private-sector companies began reshaping their organizational structures even earlier. The concepts of flexible, firm, VUCA (volatility, uncertainty, complexity, and ambiguity) and global network-centric organization and others were focused on possible reforms of the way organizations are managed. Critics of the Weberian bureaucracy argued that it is obsolete and belongs to the era of Modernity since we are living in Post-modern conditions where contracts are short-term, relationships require networking, and structures are flexible. This global and organizational evolution produced a whole variety of optimistic views representing de-regulative trends, including a shift to more personal freedom.

Indeed, the old-fashioned Weberian bureaucracy with its set of strict rules and restrictions imposed a professional control over the worker. The analytical space of the 
workplace controls what should be done by each particular worker, as well as how and when. The lack of freedom under bureaucratic conditions appears obvious. This is the reason why Weberian bureaucracy as a concept was opposed by many for decades.

The opinion about the bureaucracy as a source of total control without any freedom nearly represents the Marxist idea of the contradiction between positive and negative freedom literally. Negative freedom destroys the obstacles and rules which prevent an individual of doing certain things, while positive freedom is the capacity of the individual to do certain things.

The negative freedom of a supposed de-bureaucratization has its price, which is, paradoxically, positive freedom. Deregulation in corporate and public-sector organizations means risk-shifting from the government and business to the employee who now becomes overburdened with the defense of social and labor rights that used to be public services (for example, this is obvious in the cases of healthcare and labor legislation). To be disciplined by bureaucratic governing also meant, in a way, to be protected by the same rules that controlled one's behavior and, for example, to be able to plan for the future, or to build a career according to unchanging rules.

Weberian bureaucracy revealed itself when exposed to critical changes in the global economy, namely the spreading of precarity, flexibility, and uncertainty. To adapt to these changes, organizations have to be flexible and transform rigid forms into more flexible forms. As it was stated a century and a half ago by Marx and Engels, "all what is solid melts into air." Bureaucratic structures melt into markets and networks while trying to adjust to these circumstances (Olsen, 2007).

These changes could be understood through the lenses of Foucauldian analysis in the same manner as I subjected the Weberian bureaucracy to. Foucault did not finish his work with the concept of disciplinary power. In his later works at the end of 1970s, he proposed the new concept of bio-power, or the "care of the self," which was further developed by Gilles Deleuze to become the concept of "control society." According to Foucault, the disciplinary power over actions and behavior a posteriori during the process of activity from the 18th century is being replaced by the preventive power over self-control and self-surveillance. Bio-power is internalized in the norms and representations of the subject, that is, the technologies of the self. The new individual is controlled by themselves and is not punished with rules and restrictions, but by the risks of being exposed to social risks of illness, unemployment, poverty, etc. In other words, the regulation is implemented in the subject who is now responsible for self-regulation and taking care of themselves.

Gille Deleuze elaborated Foucault's argument in the form of what he called the "control society" (1992). Unlike the disciplinary society, the society of control aspires to demolish old barriers and rules. Instead, it provides individuals with the freedom to do whatever they want. Workers are free from the enclosed workspace, strict rules, uniforms, etc. Instead, the control society establishes a constant monitoring and tracking of individual activities. You can do whatever you want, but everything will be monitored and recorded.

The process of de-bureaucratization starts with the blurring of the boundary that separated the professional life of an individual from their personal life. In what is usu- 
ally called "post-bureaucracy" (Hakan Yuksel, 2016), or network-shaped entrepreneurial organizations, the individual's professional and personal lives melt into one perpetual lifestyle where personal abilities and skills are as important as technical skills, and one has to mix personal and business contacts to be successful. It is reflected in the widely-used concept of work-life balance which demonstrates the attempt to re-establish the boundaries missing between the personal and working lives.

The reason for this is the changing nature of labor. Labor becomes immaterial; in other words, it involves the manipulation of intangible objects, for example, information (Berardi, 2009). This type of labor does not require complex and expensive means of production, as most of it can be done by means of electronic devices such as a smartphone or a laptop. These circumstances change the conditions of the labor process, the alienation of labor, and management into more flexible ways.

Following these trends, modern organizations dismantle the traditional disciplinary instruments (rules, codes, and regulations), thereby giving room for more flexible and even (at first sight) democratic inter-organizational relations. Big corporations introduce flexible working hours, get rid of dress-codes, and detailed corporate rules and formality in communications.

The full working-time that existed in the Weberian bureaucracy as an imminent characteristic of the workplace was transformed to such an extent that it consumed personal time. To the same degree, one's personal life is consumed by professional purposes and career building, subordinating the life of an individual in the pursuit of promotions and larger salaries. The notion of soft skills (personal psychological characteristics) as a skill required in the workplace is essential in understanding how the post-bureaucracy devours private space. This labor "involves the investment of subjectivity" while "[t]he worker's personality and subjectivity have to be made susceptible to organization and command" (Lazzarato, 2012). Flexible working hours spread beyond the standard working time, and force a worker to work overtime, at home or during weekends.

The same thing is happening with the typical bureaucratic professional vocation. Instead of life-long professional individuals who had to adapt to a variety of small tasks and acquire situational competencies, workers come to be involved in a multitude of flexible employments, activities, and projects. The umbrella term for such a situation is 'precarious work', which reflects the instability and uncertainty in one's socio-professional status and employment (Bobkov, Kvachev, 2017). This, of course, implies that training should become more flexible and task-oriented; the classic scholastic education should be replaced by lifelong-learning oriented towards exclusively practical aims.

The jurisdictional areas in the post-bureaucratic organization became as fuzzy as working hours and professional status. The new project capitalism (Boltanski, Chiapello, 2017) operates outside the classic division of functions and responsibilities, creating a mixed space of multi-functional interactions and boundless project teams. The AGILE methodology teaches how to reshape organizations in order to increase efficiency through diffusing the hierarchical order of functions, that is, to do each project with 
multiple teams, which is faster and results in projects being completed at an improved level at the same time.

In terms of hierarchy, teams are formed to work on each separate project. The postbureaucracy tends to refuse the classic hierarchy structure of dividing the organization into departments. Instead, it tries to establish networks which allows for the creation of teams with members who are in line with the project's tasks.

Detailed techniques of regulating the behavior of the individual no longer exist. In the workplace, the worker is now relatively more "free" to do whatever they need to do to attain the desired results. The freedom provided in particular actions is subordinate to the organizational goal. Additionally, it releases the worker from some out-moded regulations such as a dress-code, or from the obligation to sit in front of a computer all day.

This all appears as freedom from old bureaucratic restrictions. At the same time, it is clearly only a negative freedom. The de-regulative lack of positive freedom paradoxically leads to even more regulations that only now appear as self-control and self-surveillance. This new networking bureaucracy, being very microscopic (mostly due to novel technological opportunities) and de-regulative at the same time, restructures the power relations in the organization in a way that produces behavior which leads to atomization and individualization without freedom. This phenomenon needs to be studied using the Weberian theoretical apparatus. Maravelias argues that the post-bureaucracy "continues and in certain respects intensifies the process of rationalization of human conduct that bureaucracy set underway" (2003: 551-552).

This rationalization reaches far beyond traditional professional competencies, but involves personality and individual qualities as well. The influential Harvard Business Review describes the process of managing network organization in writing that "in a connected age we need to instill passion and purpose around a shared mission" (Satell, 2015).

Instead of Fordist "docile bodies" (the Foucault formulization) in the networking bureaucracy, we have docile mindsets trained to be motivated and indoctrinated with the corporate culture. The bureaucracy exists not in the formal rules but in the attitudes and values of workers, manifesting itself as a specific structure of thinking. Instead of the Weberian "iron cage," the individual is trapped in the "iron net" which allows the individual to move freely, but each move entangles the individual more and more.

Network organization (or post-bureaucracy) through means of ICT creates systems of control which are exactly in line with the Deleuzian interpretation of Foucault. The worker is controlled by CCTV monitoring, a complicated system of PC-surveillance, or digital access badges designed to monitor the worker's presence at the work place, etc. Just like the control society in Deleuze's theoretical constructs, the post-bureaucracy acquires the shapes of the control organization. Giving freedoms in the framework of attaining organizational goals imposes massive and scrupulous supervision.

These are two major characteristics of the networking bureaucracy. The network, of course, has been developing since ICT technologies and the Internet provide the opportunities to develop networking communications and to restructure working activities through online-platforms and applications. In this case, the networking organization has 
been characterized as "uberized," so-called after Uber, which was one of the first companies to introduce such technologies in the management and communication process. As a result, this process had been called "uberization."

It is important for the networking bureaucracy to be organized through the means of ICT. Some researchers argue that this implies not a de-bureaucratization, but a rebureaucratization (Hodgson 2004), thus reviving principles of the Weberian bureaucracy in Post-modern conditions. Moreover, ideal types of bureaucracy and post-bureaucracy are hard to find in real life; for example, empirical study conducted in 2009 identifying characteristics of bureaucratic and post-bureaucratic workplaces showed that these features are usually mixed in one organization, or even in one job (Bolin, 2009).

Perhaps the final idea of reforming Weberian bureaucracy into a network is not personal freedom (at least, not positive freedom), but the process of increasing the efficiency of the bureaucratic means of control in the more flexible and fast-changing world. The famous philosopher Slavoj Žižek who wrote The Puppet and the Dwarf (2003) puts the problem this way; let us imagine two different fathers; one is the old-fashioned traditionalist who gives his children direct orders of what to do, while the other is a liberal postmodern father who, without direct orders, convinces the children that they should do something for their own sake. The latter, even if it is not authoritarian, is much more dangerous because he tries to manipulate and assure that what you have to do, you have to do for your own good. This is what is happening with networking bureaucracy; you do not have to obey strict rules, but, instead, you just have to be compliant to the conditions provided in the workplace. In the old-fashioned Weberian bureaucracy, the rules said that one should correspond to certain requirements; the networking bureaucracy provides one with opportunities and if one does not use them, it will lead to bad consequences for that individual only. In other words, the networking bureaucracy controls conditions instead of actions.

The concept of human capital (Becker, 1993) is used to transform the bureaucratic hierarchy and rules into the framework of conditions. According to this concept, each individual is a holder of their personal human capital, and have to do their best to use it to create personal income. The purpose of the organization is to provide conditions for each individual to develop their own capital and for income-generation. This will immediately lead to mutual benefits for the individual and the organization.

However, the creation of conditions implies that if one does not comply with this framework, it is the individual's fault, rather than the mismanagement of the organization or the state. Responsibility for personal actions and even well-being as a result of personal income shifts from the employer within labour relations to commercial-like networking relations, being as flexible and precarious as it is possible under modern legal and economic conditions.

Thus, the networking bureaucracy comprehends new, flexible, and innovative means of control and regulation through the creation of conditions and frameworks. The separation from formal Weberian principles did not mean de-bureaucratization, but a new form of the bureaucratization of networks. The complex study of these new forms is yet 
to be done. Weber's legacy in this context might be important to understand these processes, and to reveal new forms of control and management.

\section{References}

Agamben G. (1998) Homo Sacer and Bare Life, Stanford: Stanford University Press.

Argyriades D. (2010) From Bureaucracy to Debureaucratization?. Public Organization Review, vol. 10, no 3, pp. 275-297.

Becker G. S. (1993) Human Capital: A Theoretical and Empirical Analysis with Special Reference to Education, Chicago: University of Chicago Press.

Berardi F. (2009) The Soul at Work, Los Angeles: Semiotext(e).

Blau P.M. (1956) Bureaucracy in Modern Society, New York: Random House.

Bobkov V., Kvachev V. (2017) Precarity: Local Disorders or New Global Order?. Russian Sociological Review, vol. 16, no 4, pp. 72-86.

Bolin M. (2009) The Importance of Organizational Characteristics for Psychosocial Working Conditions and Health. Available at: https://www.diva-portal.org/smash/ get/diva2:200888/FULLTEXTo2.pdf (accessed 17 June 2019).

Boltanski L., Chiapello E. (2017) The New Spirit of Capitalism, London: Verso.

Coase R. (1937) The Nature of the Firm. Economica, New Series, vol. 4, no 16, pp. 386-405.

Deleuze G. (2006) Foucault, Minneapolis: University of Minnesota Press.

Deleuze G. (1992) Postscripts on the Societies of Control. October, vol. 59, pp. 3-7.

Evans P., Rauch J. E. (1999) Bureaucracy and Growth: A Cross-National Analysis of the Effects of "Weberian" State Structures on Economic Growth. American Sociological Review, vol. 64, no 5, pp. 748-765.

Foucault M. (1975) Discipline and Punish, New York: Vintage Books.

Hakan Yuksel A. (2016) Visiting the Iron Cage: Bureaucracy and Contemporary workplace. Labor and Employment Relations in a Globalized World: New Perspectives on Work, Social Policy and Labor Market Implications (eds. T. Dereli, Y. P. Soykut-Sarica, A. Sen-Tasbasi), Berlin: Springer, pp. 277-288.

Hodgson D. (2004) Project Work: The Legacy of Bureaucratic Control in the Post-Bureaucratic organization. Organization, vol. 11, no 1, pp. 81-100.

Jacques E. (1986) A General Theory of Bureaucracy, Portsmouth: Heinemann.

Lazzarato M. (2012) Immaterial Labour. Available at: http://frontdeskapparatus.com/wp/ wp-content/uploads/2012/10/Immaterial-Labor-Maurizio-Lazzarato.pdf (accessed 17 June 2019).

Maravelias C. (2003) Post-bureaucracy: Control Through Professional Freedom. Journal of Organizational Change Management, vol. 16, no 5, pp. 547-566.

Merton R. K. (ed.) (1952) Reader in Bureaucracy, New York: The Free Press.

Niskanen W. A. (2007) Bureaucracy and Representative Government, New Brunswick: Aldine.

Olsen J. P. (2007) The Ups and Downs of Bureaucratic Organization. Available at: https://www.sv.uio.no/arena/english/research/publications/arena-working-papers/2001-2010/2007/wp07_14.pdf (accessed 17 June 2019). 
Osborne D., Gaebler T. (1992) Reinventing Government, Reading: Addison-Wesley. Satell G. (2015) What Makes an Organization "Networked”. Available at: https://hbr. org/2015/o6/what-makes-an-organization-networked (accessed 17 June 2019).

Swedeberg R., Agevall O. (2005) The Max Weber Dictionary: Key Words and Central Concepts, Stanford: Stanford University Press.

Weber M (1925) Max Weber on Law in Economy and Society, New York: Simon \& Schuster.

Weber M. (1978) Economy and Society, Berkeley: University of California Press.

Wilson J.Q. (1991) Bureaucracy: What Government Agencies Do and Why They Do It, New York: Basic Books.

Žižek S. (2003) The Puppet and the Dwarf, Cambridge: MIT Press.

\section{От веберовской бюрократии к сетевой бюрократии}

\section{Вадим Квачев}

Доцент базовой кафедры ТПП РФ «Развитие человеческого капитала» Российского экономического университета им. Г. В. Плеханова

Адрес: Стремянный пер., д. 36, г. Москва, Российская Федерация 117997

E-mail: kvachevvg@mail.ru

Теория бюрократии Макса Вебера мыслилась как одна из важнейших предпосылок для формирования современного капитализма. Вплоть до последних десятилетий предполагалось, что идеальный веберовский тип бюрократии проник во все сферы жизни и управления, в корпорации и государственное управления и даже является паттерном, организующим саму современную социальную жизнь. Сегодня веберовскую бюрократию как теорию и практику постоянно критикуют за жесткость, архаичность и неэффективность. Современные организации в условиях позднего капитализма претендуют на то, чтобы быть более гибкими и адаптирующимися к переменам. В настоящей статье обсуждается возможность концептуализации нового типа бюрократической организации - сетевой бюрократии. Автор комбинирует фукинианский и веберовский подход к анализу социальной организации, в частности, то, что Жиль Делёз называл «диаграммами Фуко», то есть диспозициями людей, вещей и пространств, выражающими отношения власти. Автор предлагает картину сетевой бюрократии, уходящей от укорененности в дисциплинарной власти к децентрализованным практикам эпохи позднего капитализма. Сетевая бюрократия предлагает гибкие инструменты контроля: гибкие рабочие часы, отсутствие жестких правил, устранение формализма в коммуникациях и рабочем процессе. Однако эта мнимая свобода дерегулирования оборачивается новой формой контроля. В отличие от классической веберовской бюрократии, контроль осуществляется посредством делегирования, создание системы самоконтроля индивидом своей собственной работы через совокупность мер скрытого паноптического наблюдения: видеокамеры, отслеживание действий сотрудника за компьютером, контроль времени пребывания на работе через электронные пропуска и т.п. Эти новые сетевые формы бюрократического контроля предполагают микроконтроль за действиями работника с помощью новых технологий и таким образом реструктурируют устаревшие отношения власти, еще сильнее уменьшая пространство личной свободы и усиливая атомизацию индивида.

Ключевые слова: Макс Вебер, Мишель Фуко, бюрократия, сети, неолиберализм 